\title{
Patrimonialism. What is behind the term: ideal type, category, concept or just a buzzword?
}

\author{
Mikhail Ilyin, National Research University Higher School of Eco- \\ nomics
}

\begin{abstract}
The terms patrimonialism and neo-patrimonialism designate significantly different conceptual instruments. They are used to identify and interpret a range of phenomena. Using as a point of departure Weberian types of partimonial rule the author reconstructs the prototype of patrimonial order. Its key element is an inherent insight of mutual patrimony or patrimonium. It is both instrumental and essential common good that helps to keep together not only the rulers and the ruled but the entire patrimonial order. This and other morphological pattern of order are nothing but 'blueprints' for making conflicting desires of order come actual and real. Historical achievements and current practices provide a range of patrimonial hybrids and admixtures to political setups of all kinds. All those arrangements can be interpreted as metamorphoses of the prototype patrimonial order. The author particularly highlights the tripled knot of patrimonialism, bureaucracy and modernity in the current political practices. Conceptually coherent analysis of both functions and dysfunctions of patrimonialism helps to see the potential of patrimonial patterns of order in the ongoing political process. Insufficient and blurred conceptualization of patrimonialism let its dysfunctions loose and deprive us of abilities to overcome them.
\end{abstract}

Keywords: patrimonialism, patrimony, neo-patriomonialism, Max Weber, evolution

For more then four decades the word form patrimonialism in its various national transliterations along with its even more popular derivative neo-patrimonialism get ever widening usage in political and social discourses. Along with it phenomena that are referred to by the respective words are questioned and 


\section{Redescriptions 18/1}

debated in across the vast spectrum of social sciences. Despite a buildup of important findings and insights the overarching confusion is getting ever wider.

To overcome confusion rectification of words long acclaimed by Confucius is to be coupled with respective elucidation and analytical disclosure of the phenomena themselves as well.

\section{Varieties of word use}

Terms of reference may have a range of dissimilar sorts of meaning that single out specific aspects of the phenomena they refer to. Terms are entities of diverse kinds. They may be fairly different semiotic devices or even referential and denotative contrivances.

Within the overall nomenalist tradition they may be used as conventional terms that can be unambiguously specified. In this case a strict definition is to be provided at the very outset. No diversions from the conventionalized meaning would be possible then.

Within broadly construed realist tradition it is possible to use the terms as if they refer to abstract objects in Platonic sense. Such usage is often imbued with exaggerated similarity between an idea and corresponding phenomenon. Eventually this often leads to naturalistic identification of the idea and phenomenon. Finally, in extremo dedifferentiation of all the three components - the term, the idea and the phenomenon - provides their ultimate integrity.

Within a range of mid-way conceptualist approaches terms could be instrumentalized to grasp or conceive phenomena. They may be treated as generalized abilities, instrumental universals, e.g. Aristotelian hylomorphic instantiations or entelechies or even as categories of a kind. In both cases abstract object or instrumental universal would be considered structurally homogeneous semantic crisp sets that would shun Sartorian conceptual stretching (Sartori 1970).

Terms may be used as representations of mental models. Then they would develop into structurally heterogeneous fuzzy sets of meanings. Their structure would be shaped as semantic fields or more specifically cognitive maps (Tolman 1948), radial networks (Norvig \& Lakoff 1987, Brugman \& Lakoff 1988), prototypes (Rosch 1973, Rosch 1978), concept maps (Novak 1993, Novak \& Cañas 2006) etc. Conceptual variations could be characterized then by family resemblances (Wittgenstein 1951/1975, Rosch \& Mervis 1975).

It is only to be expected that the use of the terms patrimonialism and neopatrimonialism is justified by references to Max Weber's ideal and other kind of types. Being heterogeneous semiotic devices and fuzzy cognitive appliances, Weberian types focus on properties that are deemed typical. Criteria of typicality must needs be very subtle, combing specific but indispensable indications. 
In fact typicality is provided by combination of a singular outward manifestation with its internal mainstay or crucial crux.

Quod licet Jovi non licet bovi. Unfortunately much of the post-Weberian and would be Weberian typology-making is de facto reduced to normative categorization or rather simplistic classification with very few ad hoc prescribed criteria.

Finally, the terms often turn out to be nothing but ordinary language words. They are often indiscriminately repeated and to this effect trivialized. Such trivialized terms readily develop into trendy buzzwords. Their broad surface meanings are overstretched while subtler meanings are lost in the process of the stretching.

By and larger the of users of the words patrimonialism and neo-patrimonialism seem not to think about the status and character of the terms they use. A few authors that make occasional remarks to that effect would not consider all the options or explore their own guess systematically. The present article is an attempt to raise the issue and to suggest some possible ways to approach it. It is far from being just an exercise in semantics. On the contrary it aims to clarify alternative approaches to patrimonialism in current social research.

\section{From Patrimonialstaat to current notions}

The German adjective patrimonial was long used both absolutely and in compound words like Patrimonialstaat or Patrimonialgerichtlichkeit. Since the period of turbulent 1848 the adjective was more and more used to characterize traditionalist ideology and style of rule. In fact it was specifically applied to adherents of the so-called patrimonial state (Patrimonialstaat). In its turn the word Patrimonialstaat habitually referred to hereditary monarchy in Germany. Only in early $19^{\text {th }}$ century eminent Bernese conservative politician and legal constitutionalist thinker Karl Ludwig von Haller extended the notion of patrimonial state to a much broader and loftier understanding (Haller 1816-1834). He contrasted naturally sociable condition (natürlich-geselliger Zustand) of the patrimonial state to artificial (künstlich) creatures (Chimäre) of military states (Militärstaaten), clerical states (Priesterstaaten) and republics. Furthermore, Haller derived the origin of the state and the very political order "from the initial patrimonial community" (auf ursprünglichen Patrimonialverband) (GG 6: 49-50). It was Haller's broadening of the idea of hereditary rule to a natural rule opposed to its 'unnatural' alternatives that set up conceptual developments ironically ending up now with the word patrimonial referring to something distorted and deviant.

What are Haller's notions of the initial patrimonial community and the resulting patrimonial state? Nothing but abstract objects that exist on their own 


\section{Redescriptions 18/1}

in realist sense. But they can also be applied to existing phenomena. It was a common practice of the age to link 'real' abstract notions to genera of specific objects (and it is deep entrenched in our present-day thinking even now). Thus, an outstanding German scholar Robert von Mohl who gave a detailed account of Haller's work in his Geschichte und Literatur der Staatswissenschaften (II 529-60) singled out a range of classes or rather genera of states (Staatsgattungen) in his other seminal work Die Polizei-Wissenschaft nach den Grundsätzen des Rechtsstaates (3 vols, 1832-1834).

"The religious orientation of life (Lebensrichtung) produces theocracy, the morally digressed (sinnlich verkümmerten) one produces despoty, the claims of private law patrimonial states (der privatrechtlichen Forderung des Patrimonialstaats), a simple family approach patriarchal state (Patriarchalischer Staat), the morally understood meaning of life rule of law state (Rechtstaat)" (Mohl, 1844: 15).

The further history of the word Patrimonialstaat in German political discourse by and large produced an uneasy assortment of traditional understanding of a hereditary monarchy and of the Hallerian vision of a universal and primal practice of traditional rule. It was only by the end of the $19^{\text {th }}$ century that the word Patrimonialismus entered German political vocabulary. It referred to a wide range of political attitudes, styles of behaviour and practices typical for proponents of traditional rule. By that time initial reference to a specific set up for German and European hereditary monarchy was by and large marginalized. In this context it was quite predictable that Max Weber would resort to the word in his grand outline of basic types of rule. It was far more broad and flexible then either Patrimonialstaat or Patrimonialverband. But what is even more important the new term was in fact a new analytical device. It allowed to shift from abstract 'essences' to focal properties or typicality of various patterns of rule.

It was "Economy and society" that emerged as a landmark in elaboration of new semiotic devices and the study of the very phenomenon of patrimonialism. Most probably Weber himself never consciously intended to sum up previous interpretations of patrimonial state and rule in a clear and coherent way. He probably never cared to acknowledge respective conceptual and lexicographic history. He would not specifically elaborate on the Roman notion of patrimonium that was at the bottom of the conceptual history. He could have his pragmatic reasons to do so. But a current student of patrimonialism cannot ignore its conceptual background. It would be superfluous to resort to a long conceptual history of debates about patrimonial state, respective traditions and ways of rule in a short article with a specific focus. But some references to key moments are evidently necessary. 
Weber has adopted the term quite late in his academic career. He did it only in 1914 after reading a book Der deutsche Staat des Mittelalters written by his friend Georg von Below (Breuer 2006: 88; Bruhns 2012: 13), who opposed links between Patrimonailstaat and Landesherrschaft. Below's arguments helped Weber "to introduce a clear distinction between patriarchalism and patrimonailism, i.e. between the level of 'household (oikos)' and that of a political entity" (Bruhns 2012: 13).

Anyway pragmatic departure point would be German word Patrimonialstaat meaning just hereditary state. The word-form was used just to stress the key role of legal inheritance of the title to power or patrimonium in medieval Latin or in Roman Law. That would entail implications of transfer of rights and entitlements. The respective cognitive model was three-fold: ancestor (entitlement holder, benefactor) - vehicle of entitlement transfer - successor, heir (entitlement recipient). This tripartite conceptual structure would be implicitly preserved in deep layers of lexicological 'memory' of German and other European languages. This structure would also make it possible to extend reference from purely interpersonal or intrafamilial contest to broader social context of generational interaction and temporary continuance of societies.

The tripartite conceptual structure of social persistence would mingle with the concept of tradition. With the proliferation and ensuing preeminence of developmental or rather progress-historicist mode of thinking the traditionbound components of overall patrimonial idea were radically discredited and mentally rejected. It was in this context that in late 60 s the terms patrimonialism and neo-patrimonialism got wide use in political and social sciences the (Roth 1968; Eisenstadt 1973; Pipes 1974).

The scholars of patrimonialism and neo-patrimonialism would not recognize their inherent conceptual revisionism. Many would not even notice it. They would not care of the conceptual history. Rather they would typically resort to specific and arbitrary selected instances of word-use by Max Weber as the appealing precedent. Many would even claim that the terms they used are ideal types though in fact they would refer either to abstract objects (general normative idea of patrimonialism as they interpreted it contextually) or just blurred notion of ordinary language.

The lack of conceptual clarity and terminological discipline explained why the terms' "theoretical status was not properly defined" (Maslovski- 1996: 296). A voguish craze to draw on the words patrimonialism and neo-patrimonialism would make them "used rather indiscriminately" (Maslovski 1996: 296-297). In fact the term patrimonialism tended to become 'something of a catch-all concept, in danger of losing its analytical utility' (Theobald 1982: 555).

By now the notions patrimonialism and neo-patrimonialism have been overstretched both by further extension of the conceptual domain and by shifting a semantic focus to very specific attributes of respective phenomena. This in fact 


\section{Redescriptions 18/1}

makes them new distinct notions that have radically different semantic profiles with occasional traits forming a prototype core. Thus two highly knowledgeable experts on African politics would claim the very essence (sic!) of neopatrimonialism to be "the award by public officials of personal favors, both within the state... and in society..." (Bratton \& van de Walle: 458). Neopatrimonialism could be seen as a synonym for corruption, clientelism, patronage, cronyism, nepotism, the "big man" syndrome, godfatherism, warlordism, capture, predation, kleptocracy, prebendal regime, etc. (Evans P. 1992) or it may be side-tracked to the "common denominator for a range of practices that are highly characteristic of politics in Africa, namely nepotism, clannish behaviour, so-called 'tribalism', regionalism, patronage, 'cronyism', 'prebendalism', corruption, predation, factionalism, etc.” (Medard: 330). Typically negative features crucial for very specific research interests or political contexts are treated as central and essential.

With each new application of the terms to countries, regimes or specific practices respective notions would refocus interpretation of the phenomena called patrimonial. Eventually "the 'endemic' nature of references to neopatrimonialism has contributed to its conceptual stretching. The concept gradually transformed into an 'elusive' notion" (Erdmann \& Engel 2007). It is described as a catch-all (Erdmann \& Engel 2007) concept, as dues ex machina (Theobald 1982: 555), or as a fluid (Soest 2010) notion.

What conjectures would follow from semantic disarray behind terminological homonymy? The lack of proper definition of theoretic status of the terms (Maslovski; 1996: 296) would obscure what kind of analytic instruments is used in each specific instance of the word-use. It could be anything within a range of verbal signs or terms of reference. One pole of the scale would be a strict scientific term that is precisely defined and conventionally used in an unequivocal reasoning. An opposite extremity would be a shallow buzzword which broad surface meaning is overstretched to be immediately understandable by everybody and which subtler meanings has been likewise lost in the process of the stretching. In between one would find a standard term that can be strictly defined and conventionally used in an unequivocal reasoning a homogeneous concept that shuns Sartorian conceptual stretching, a heterogeneous notion with core prototype or radial network structure that incites Wittgensteinian family resemblances, a Weberian ideal type or just an ordinary language word.

The reference of the terms also appears uncertain. Using the same term various authors (and sometimes even one author within a single paragraph) apply it to (1) abstract entities (be they objects - visual Platonic ideas or abilities instrumental Aristotelian universals), (2) mental models or types with varying degrees of generalization or abstraction, (3) phenomena with equally various degrees of their extraction or 'visibility' by highlighting this or that set of qualities or distinctive features. 
The term patrimonialism currently refers to a very broad range of phenomena including various types of governance. Still its application is much broader. It implies a way of life, assorted mindsets, a range of behavioural patterns and styles of human interactions. With each new application of the terms to countries, regimes or specific practices respective notions would refocus interpretation of the phenomena called patrimonial. It would be essential to identify aspects of life and respective phenomena which the term may be applied to. In this case it is actual governance or rather its existent kinds, to be precise political orders, institutional setups and practices that could be empirically detected and studied. This task would imply singling out diagnostic properties that are essential to comparative or empirical analysis of actual cases of patrimonial governance. But before undertaking such an attempt it worthwhile to consider patrimonial conceptual range in Weber's works and beyond.

\section{Weberian varieties of patrimonial rule}

Max Weber not only introduced the term patrimonialism but also provided substantial interpretations of specific cases, particularly historical types of Egyptian (Ptolemaic), Chinese (Qin), Russian (Romanov) and English (Tudor) patrimonialism (Weber 1980: 130-140, 580-625). Those historical types refocus the ideal type elaborated in the third chapter of the third part of "Economy and Society" (III.3.). A number of further interpretations of patrimonialism in the book always have references to specific historical practices.

Some authors tend to believe that Max Weber developed a genuine ideal type of patrimonialism (Kalberg 1994: 96-97). Others would deny it and even question coherence of Weberian conceptualization of patrimonialism (Anderski 1984: 48, 111). Some identify variation within Weberian conceptual domain of patrimonialism (Maslovski 1996; Charrad \& Adams 2011). Thus, Charrad and Adams stress, "Patrimonialism can characterize a relationship as limited and stylized as the classical Weberian triad of ruler-staff-ruled, or as rich and complex as the system of power characterizing a national state. It has also been mobilized —including by Weber himself_-as a key to understanding the rise and fall of world empires, which preexisted the rise of the nation-state and persist as a counterpoint to contemporary states and interstate relations" (Charrad \& Adams 2011: 8). In his turn Mikhail Maslovsky notes that "in his discussion of patrimonialism Weber employs three different concepts: patrimonialism proper, sultanism and estate-type domination". He further concludes that "apparently all of them should be treated as separate 'pure types', which are, nevertheless, interrelated and comprise a particular ideal-typical model". Eventually "patrimonialism can be regarded not as a separate pure type but as 


\section{Redescriptions 18/1}

a system of such types" (Maslovski 1996: 298; cf. Масловский 1997).

A great discrepancy in treating terminological and analytical instruments of Weber may result from heterogeneity of his oeuvre. In fact "Economy and Society" is a compilation edited posthumously by Marianne Weber and then Johannes Winckelmann. The key chapter patrimonial type of rule (III.3.) was methodically formulated by Weber himself as an essential nucleus for his Grundriss der Sozialökonomik. The chapters that were incorporated later into Herrschaftssoziologie (IX 3. and 4.) remained descriptive notes or even "sketches" to sum up factual material. While in the first case pure type instruments are used in the later cases they are historical type at best or even rough notions.

In actual fact Weber uses a range of conceptual instruments from notions to pure types. The starting point is a word of ordinary language or rather the cognitive scheme (metaphor) that underlies it. The next stage is that of broad and vague notions having a prototype core and a broad conceptual periphery. Historical types would be more coherent conceptual tools developed by reducing both their volume and content by a very easy procedure of dropping all 'alien' data and characteristics. Placing together of a few historical types and focusing on their common features while dropping specific would produce analytical concepts. Their further refinement would produce ideal types and eventually pure types.

Weber developed and used not only ideal types, but a whole range of analytical instruments and a number of types of different level of abstraction up to historical and boarder types. Very often they were shaped by specific research interests that Weber pursued in his individual works. Weberian notion of patrimonialism is just kind of a conceptual instrument. It is more concrete and specific and more enrooted in practice then a pure type or even an ideal type.

Weber himself employs a whole range of types of different degree of abstraction - all the way from ideal type to historical and what he called border types. Weber's nomenclature includes ideal type (Idealtyp), pure type (reiner Typ), historical type (bistorischer Typ), natural type (natürlicher Typ), empiricalstatistical average type (empirisch—statistischer Durchschnittstyp), border type (Grenztyp), strict type (strenger Typ).

In his "Economy and Society" Max Weber introduced a notion of patrimonialism as a sub-type of traditional domination. While doing so he displayed a whole range of traditional domination varieties. They were 'primary' patriarchalism (primärer Patriarchalismus), rule of elders (Honoratiorenherrschaft) or gerontocracy (Gerontokratie). They are evolutionary superseded by secondary types of rule. Weber himself never used that qualification but it is clearly implied. Those secondary types of rule include patrimonialism (Patrimonialismus), sultanism (Sultanismus), and estate domination (ständische Herrschaft). Patrimonial rule emerges not as a single pure or ideal type but rather as "a system of such types" (Maslovsky: 298). All those sub-types belonged to an 
encompassing type of traditional domination which potentially could be upgraded to an ideal or even pure type.

One should not expect consistency in the use of all those types by Weber. It was very much determined by his specific goals for writing this or that text. One should not forget that "Economy and Society" is after all a collection of assorted texts. Still in $\$ 6$ of section 3, chapter 3 of the first part of "Economy and Society" Weber gave a systematic explanation of the traditional domination and its types. He essentially identified it as a personal (!) rule of one or more lords (Herren) by the virtue of 'their manifest personal esteem' (ihnen zugewiesenen Eigenwürde) and defined respective polity as 'reverence community' (Pietätsverband):

"A rule should be called traditional if its legitimacy is confirmed and understood on the basis of sanctity of the long-established ("evident to everybody") orders and ruler authority (Ordnungen und Herrengewalten). Inasmuch the ruler (or several rulers) are recognized by the tradition-wise obtained ruling (traditional überkommener Regel). They possess power to the effect of their own self-righteous standing (ihnen zugewiesenen Eigenwürde). In its simplest incidence the community of ruling is primarily a reverence community shaped by concerted upbringing (durch Erziehungsgemeinsamkeit)" (Weber: 130).

The ideal type of traditional domination had two dimensions: "material tradition-bound exercise of domination" (material traditionsgebundenen Herrenhandelns) and "material tradition-free exercise of domination" (material traditionsfreien Herrenhandelns). In other words it extended from a 'pure' extreme of being tradition-bound to another 'pure' extreme of being tradition-free. Within this range Weber placed a series of historical types just mentioned above. Their sequence from 'primary' and thus nearly 'pure' patriarchalism to estate domination (ständische Herrschaft) could be explained by gradual decrease of tradition-bound domination and equivalent increase of tradition-free domination. Similarly primary patriarchalism was a direct interaction of the ruler(s) and the ruled while through all other varieties some media (staff, institutions etc.) were getting ever greater prominence. Finally the sequence was also evolution advised from earlier to later historical cases.

It is crucially important to understand that Weber did not treat his types and other conceptual tools as clear-cut containers for what 'really is' in its entirety. He criticized Marxists, for example for misuse of the excellent analytical tool of capitalism by its naturalistic identification with the reality out there (Weber 1904, 204-5). It means that patrimonialism is not the thing out there but what we can see in the world around using the tool. It is only one aspect along the other ones within encompassing results of analysis and verstehen 


\section{Redescriptions 18/1}

when two or more tools are used simultaneously. In such cases Weber often developed new types like Caesarism etc.

This analytical and historical logic would allow to place just after estate-type domination and close to the tradition-free and present day 'pole' some other types of domination. The most 'advanced' one is that of neopatrimonaialism introduced a few decades after Weber. But there are or rather were at least three more introduced by Weber himself but not discussed by him in detail in "Economy and Society". They were Caesarismus (Cäsarismus), rule of officials (Beamtenherrschaft) and plebiscitary domination (plebiszitäre Herrschaft). Those new types of rule may be considered tertiary compared to primary set of patriarchal and secondary set of patrimonial one. Still they are clearly entranced in patrimonialism with its triple Weberian formula ruler-stuff-ruled. Caesarism shifts focus on the ruler, rule of officials on the stuff and plebiscitary domination on the ruled. Weber described the historical type of Caesarism as a new departure having clear patrimonial properties (Weber 1994; cf. also Baehr 2004). Another version of patrimonialism was defined as rule of officials (Beamtenherrschaft). Those two Weberian denomination may be seen as a further extension of the conceptual family of patrimonialism into the domains of legal-rational and charismatic domination. In fact plebiscitary domination (and democracy) is a further development within the same conceptual continuum. All the three types constitute an overlapping set of highly ambiguous types combining patrimonial qualities with legal-rational ones and in the case of plebiscitary domination also charismatic properties.

This is equally true of neopatrimolnialism. By all standards - as its very naming suggests - it is infused with patrimonial properties. But the prefix neo- also suggests that it extends beyond limits of traditional domination into legal-rational domain.

We are not to discuss here what Max Weber 'really meant'. His attributions of the terms from patrimonialism to caesarism and plebiscitary domination were advised by his specific research questions and the context of his times and political momenta. It is true that "patrimonialism can characterize a relationship as limited and stylized as the classical Weberian triad of ruler-staff-ruled, or as rich and complex as the system of power characterizing a national state. It has also been mobilized - including by Weber himself - as a key to understanding the rise and fall of world empires, which preexisted the rise of the nation-state and persist as a counterpoint to contemporary states and interstate relations" (Charrad \& Adams 2011: 8).

Patrimonialism occupies the central place within the sequence of traditional kinds of domination. While primary patriarchalism is largely tradition-bound and estate domination is relatively tradition-free, with patrimonalism both trends are to be more or less balanced. 
What brings together all those different kinds of traditional domination? What tradition rest upon? Generations of rulers as well as historical types of rule come and go but something remains a vehicle of 'dragging on' habitual domination. That vehicle is some constant medium that links the rulers and the ruled. Weber often but not exclusively identified this link as this or that kind of staff. But it is more then changing and specific kinds of staff. They also come and go. The vehicle is something that transcends the stuff as well as the rulers and the ruled. It is something common to all of them. A theoretical abstraction of common good may be probably the best expression to describe it at the outset. But it would be not the optimal choice for two reasons. First, the very term common good is highly charged and has very specific connotations in an assortment of ideologies. Second, the very notion extends far beyond domain of traditions into the broadest possible sphere of values. Still it very accurately points at the functional load of the key patrimonial medium.

\section{The prototype of patrimonial orders}

Types may and should vary in accordance with research design, or approach of a scholar. It is necessary to control oneself and the instances of typicality you use as Weber insisted in his seminal objectivity article and other methodological pieces. Lack of control may lead to arbitrary conceptualization and buzzwording described earlier. A way to prevent such developments is to move from typical to prototypical. Behind varying typified phenomena one can discern sketchy contours of what Goethe called das Urphänomen. It is perceived with the help of prototype or type that withstands variations and focus on deeply entrenched properties of respective phenomena.

Cognitive science and psychology regard prototypes as modes of graded categorization, where some members of a category are more salient or important than others. Strictly speaking types are similar graded categories. The difference is created by criteria of salience. They may have purely psychological foundations, like in exemplar and prototype theories. But they be treated differently, namely in a morphological perspective. In this case cognitive schemata or patterns used would identify not the arbitrary features of the phenomenal configuration however outstanding they may look from ideological, cultural or psychological perspectives. They are stable and subject matter bound structures of phenomenal configurations.

In our research addenda of this article it is much more appealing to look not so much for unique embodiment(s) of patrimonialism (as do majority of neopatrimonialism scholars) but for an analytical instrument that may help to identify patrimonial characteristics in a variety of cases. In fact Max Weber has done a significant part of the job delineating pure type of patrimo36 


\section{Redescriptions 18/1}

nial rule. The origins of patrimonial governance or rather its cradles are tribal orders and ways of life that were defined by Max Weber as 'primary' patriarchalism (primärer Patriarchalismus), rule of elders (Honoratiorenherrschaft) or gerontocracy (Gerontokratie). As long as violent or peaceful integration of tribes and kinships made it impossible to use direct ways of primary governance it became imperative to reshape the habitual patterns of governance into novel ones.

The initial and the simplest modes of governance are characterized by a closed access and vocal communication restricted by ability to hear and interact with each other. The primordial self-enclosed enclaves numbered a few dozen folks and were maintained by their biological flock reproduction inherited from pre-human primates. They also developed first proto-human and then increasingly human social reproduction fashioned by immediate vocal interaction and daily routine playing of procreation roles. Vocal speech and lineage were essential communication and governance tools. Authority was not was purely functional and was not structurally detached from an entire primordial kin group. Morphologically the closed human communities were reproduced by the 'blueprints' or memes of ancestral lore transmitted in by oral narrative and familial rites.

It was only with Neolithic and Urban revolutions that started about 130 generations from present human conditions began to change. It was then that our ancestors managed to extend their homogeneous and egalitarian primitive bands to heterogeneous and stratified asymmetrical chiefdoms. Further evolutionary forms of polis were even more densely integrated assemblages of chiefdoms and tribal leagues. With chiefdoms getting upper hand over other chiefdoms and tribes, with an emergence of tribal federations or poleis the ruler or rulers could not be maintained over populace on a regular basis. Respective structural and morphological development were triggered by the need to maintain order when direct oral communication, and to that effect getting input to work out common goals, to give orders and check their implementation became highly problematic or even impossible. The authority was de facto structurally detached from the general populace often dispersed over sizeable territories. New ways of dealing with the challenging new circumstances had to be developed.

Morphological solution of the problem was quite self-effacing and straightforward. It was creation of a link between the authority and entire populace. Specifically patrimonial solution for the problem of polity overextension reshaped tripartite division as essential unity of the prevailing authority (quasipatriarch, housemaster) and the entire populace (quasi-kinship, kinfolk, domestics, householders) provided the linkage between them (quasi-household, its instrumental aspects and symbolic representations as common legacy). The last component worked as a crucial integrative device. 
Patrimonial solution was not the only one. Patrimonial order patterns were only one kind of broader assortment of linkage patterns. There were several other alternative types of tripartite division. For example, it was a pattern of conquest with dominant authority of the quasi-conqueror, the conquered and the controlling army. Another solution was autonomous linkage bridging nominal and often minimal authority with subservient populace. There was one more pattern uniting leader with personal charisma or imposed cult of personality with 'devotees'. In this case the linkage was provided by 'priests' and other promoters of the cult of personality.

The new device of mediating link was still typically framed in a guise of customary practices. Thus, in the case of patrimonial governance it could be the staff of deputies sent out by an authority to voice orders or manage affaires of outlying surroundings. Such staff was usually conceived and functioned as a kind of a kin group (clique, retinue, cohorts). Overarching identities of broader assemblages were envisioned and articulated as ancestral law typically commandments of fore fathers. Although the linkage was purely social, non-biological, 'artificial' creation it was conceptualized in terms of invented lineages. Common staff, common lore and common lineage were conceived as mutual legacy and even birthright provided by forefathers. The proper term would be patrimonium. Respective types of political orders and varieties of governance are patrimonial. They are integrated by patrimonia - shared institutional orders and value systems thought of as 'inherited' from and provided by a common authority.

Evolutionary and morphological reconstruction of the origin and essence patrimonial rule goes well together with its Weberian vision. In Weber's view the common rationale and justification of patrimonialism rest on a residual ability to maintain a 'reverence community' (Pietätsverband) in changing contexts of any type. What is to be revered by members of the community? At first glance Weber's answer is not what but who - the lord or lords (der Herr oder die mehreren Herren). But it is clear that they are revered not for their purely personal characteristics. Personal esteem or rather affection and even adoration are the basis of charismatic role. But even in this case charisma transcends the personality of the ruler and stands for something bigger and socially more significant. The ruler is only a vehicle and embodiment of charisma. It is not his property, but he is the 'property', manifestation of charisma.

With all their functional role reverence and piety patrimonial and other traditional types of rule are distinctly different from charismatic ones. They are essentially entrenchment or embedded within a tradition at large. Patrimonial lords are only vehicles and embodiments of what keeps 'reverence community' together. What integrates? What is the base for reverence and obedience of subjects as well as willpower and authority of the rulers? What maintains the tradition itself? It is something that could be defined as the common re- 


\section{Redescriptions $\quad 18 / 1$}

vered heritage of an entire durable (multi-generation) community entrusted to and managed by an authority that embodies it at a given moment. Let us call it common patrimony - or rather use a neutral Latin word patrimonium to cleanse it and dispose of everyday connotations of our mother languages.

\section{Patrimonium as both essential and instrumental good}

What makes patrimonium a setting up and a stake of patrimonial order? Uneasy but very indispensable combination of instrumentality and consummative self-sufficiency. It is a crucial good for the rulers, the ruled and the entire piety community. This good can and should be used as a practical resort to consolidation. But at the same time it the ultimate common good for all the members of a patrimonial community.

With all their functional role reverence and piety patrimonial and other traditional types of rule are distinctly different from charismatic ones. They are essentially entrenchment or embedded within a tradition at large. Patrimonial lords are only vehicles and embodiments of what keeps 'reverence community' together. What integrates? What is the base for reverence and obedience of subjects as well as willpower and authority of the rulers? What maintains the tradition itself? It is something that could be defined as the common revered heritage of an entire durable (multi-generation) community entrusted to and managed by an authority that embodies it at a given moment. Let us call it common patrimony - or rather use a neutral Latin word patrimonium to cleanse it and dispose of everyday connotations of our mother languages.

Are there any essential limitations for any institutional structure to be identified as a patrimonium? Hardly any. In practical terms it means that neither cultural contexts, nor evolutionary morphology may prevent a political community to single out a particular concept of order and use it as a patrimonium. It turns out to be not a generic concept based on classical genus-differentia distinction but rather an elusive and fuzzy nebula of ideas brought together by their family resemblance just like famous Wittgensteinian notion of games. In much the same way we may assume people resort to patrimonia just like they resort to games but patrimonia are just as numerous and heterogeneous as games.

It is also evident that both people and rulers would be quite free to shape or re-shape such a concept to specific historical conjunctures and daily life contexts. Patrimonium with all its trans-generation validity is also remarkably fluid and adaptable. So it is only natural that momentary aberrations like prebendalism, or tribalism, or 'big man' complex may seem to be its distinct features. 
Beyond those superfluous momentary properties lay conceptual features that are more persistent or rather recurring on a multi-generation scale. They may or may not relate to conceptual schemata deeply ingrained in cultures. Typically they could be metaphors of heritage, common good, fortune, gift, chosen destiny etc. Some of those conceptual schemata are culturally obscure and hidden while others are quite clear and manifest. Some could be even profoundly elaborated in mythologies, religions and ideologies as the case may be.

Within Roman tradition the notion was conceptualized both as patria and as patrimonium. This notion was accepted by new European languages and cultures. Needless to say that terminological choice of patrimonialism made by Max Weber was greatly predetermined by this deep-rooted tradition.

An alternative and in many ways mirror notion was and still is used by Chinese. Their idea of the Mandate of Heaven (tiān ming) may be considered as a model of patrimonium. In fact it implies not only the Divine Right of the ruler but rather his reverence to common good of the people. It is this reverence that makes the Heaven (tiān) happy - its instruction (ming) being fulfilled as well as destiny, fate, good luck and life itself (all other meanings of ming) restored.

To maintain the Mandate of Heaven the emperor has to follow it strictly and obediently. This obedience or filial piety (xiào, 孝) is a primary cornerstone of political order and the very way of life in China (Traylor 1988). In practical and personal terms mental epitome of tiān ming implies reverence relations. Imposition of 'paternal' authority from above is conceptually supplanted by submissive 'filial' obedience from below. The Chinese patriarchal domination is voiced and explained as filial obedience or respect of a 'son' to his 'father'. It is a social 'son' (minor) who is an active agent of patrimony translation rather then inactive or recipient social father (elders). One can say that Chinese patrimonialism is not patriarchal. It is filial or rather 'sonly'.

Chinese filial piety is literary carrying (and caring for) elders lao by a son $z i$ (Ikels 2004: 2-3). This duty of carrying and caring for is deemed as absolutely natural and innate. It is inherent and only thus inherited. Everybody including the highest authority should be obedient to supreme commandment or Mandate of Heaven. The whole political order rests on the imperative of selfimposed obedience.

What is essential for patrimonial world view? Persistent and consistent ('habitual') use of a mental construction of 'imagined patrimony' as a point of departure. And then people of the patrimonial 'reverence community' claim - it is all ours, it is indivisible, we all share it. Typically the ruler being one of them is still better equipped to act for each of them individually albeit not necessarily collectively. The 'imagined patrimony' is all theirs and indivisible. They all share it but the ruler takes over a major burden of doing the job of maintaining patrimonium. He is better equipped to act for each member of the 'reverence 


\section{Redescriptions 18/1}

community' and they are just to adhere to him. People are to give all possible support to the ruler and to remain faithful to him.

Patrimony may have different appearances. It may be Russian votchna (family belonging), or Chinese filial piety to the Mandate of Heaven, or Napoleonic patrie, or imagined 'stronghold of all progressive humanity' the USSR. What is important it is a common good that is taken for granted as a departure point for anything done (thinking, imagining, acting) in politics.

For many scholars of patrimonialism this refocusing from the ruler to the common good of 'reverence community' may seem odd and tenuous compared to regular and apparent perspective of the ruler and his manner of rule. But analysis centered upon a personalized ruler and his agency has its flaws. It cannot address a range of substantive questions. Why the rule of a mediocre person remains stable and despite all his wrongdoing and offence? Why developing and progress-inclined populations would tolerate corrupt personal rule against all odds? Why urbane and libertine elites of old Russia would endorse autocracy of Czars? Why emancipated and educated masses would subdue to Stalinist dictatorship despite well-entranced legacy of October Revolution? Why present generations of disillusioned and unruly Russians would welcome Putin's rule? Why many Russians readily resort to generally (and even personally!) depreciated corruption as a prompt means of personal resistance to arbitrariness of powers that be? Is there something beyond and above personal rule and corruption that justifies individual longing for preservation of life, liberty, and the pursuit of happiness? Something that makes hateful wrongs not only tolerable but instrumental?

Answers to such questions demand reshaping of Weberian conceptual dimension of authoritative domination (Herrschaft). In that perspective it must needs to shift our vision to a more general conceptual domain of consent and order. Then the core instance would be the 'reverence community' and the object of their reverence. It would be their common good and their everlasting heritage that the ruler is only momentary care-taker of. That perspective would probably allow to accept other possible care-takers of patrimonium as agents allied with the ruler or even autonomous to a degree. Typically such an agent is bureaucracy and some other modern institutions and organizations. In fact neoparimonial turn is clearly related to intrusion of bureaucracy and modernity into traditional patrimonial set-ups.

\section{Patrimonial hybrids, admixtures and metamorphoses of patrimonial orders}

Extensive study of patrimonial and neopatrimonial practices led to an impor- 
tant "analytic distinction between regulated or capped forms of patrimonialism (patrimonialism within the state) and predatory forms of patrimonialism (the patrimonialism of the entire state)" (Bach 2013: 26). With all its empirical validity this verdict can be further developed. Homogeneous polities that would entirely fulfill one and the only one morphological set-up - patrimonial or any other - hardly exist. Such a vision may be a result of a backlash of realist notions deep-rooted in our thinking. In fact predatory outcomes may attributed to effects of other admixtures to patrimonialism. In this context patrimonial hybrids, admixtures and metamorphoses of patrimonial orders are extremely topical.

The emerging fuzziness of practices does not prescribe vagueness and ambiguity of scholarly analysis. On the opposite it must be very clear and go beyond superficial appearance of the factual particulars however telling they may seem at the first glance. To better understand the perplexing knot of heterogeneous phenomena one has to resort to highly detached and definite analytical distinctions of each of its components.

A possible approach would imply building an abstract classification of various types patrimonialisms with admixtures. One can use, for example two dimensions - a Weberian and evolutionary ones. The extended Weberian patrimonial-related typology includes 'primary' patriarchalism (primärer Patriarchalismus), rule of elders (Honoratiorenherrschaft) or gerontocracy (Gerontokratie), patrimonialism proper (Patrimonialismus), sultanism (Sultanismus), estate domination (ständische Herrschaft) as well as Caesarismus (Cäsarismus), rule of officials (Beamtenherrschaft) and plebiscitary domination (plebiszitäre Herrschaft). Such a broad variation of types defined by assorted and significantly varying criteria could hardly make a single dimension that can provide both parametrical and operational variable. It would be more realistic to range patrimonialism by a degree of its inclination towards charismatic and rational-legal types and their possible overlapping. Then and only then specific historical types may exemplify main segments of a single abstract variable.

Following Weberian logic criteria for classification may be operationalized by reference to resources the dominant ruler has to rely upon. They could be broadly speaking (1) structural patterns of time-tested ways of rule and obedience, (2) a promising and convincing mission unifying people around its symbolic articulator, (3) rational calculus of consent and reduction of transaction cost through concentration of power. The first type would be an apparent patrimonialism with a historically and culturally rooted patrimonium. The second type is charismatized patrimonialism with a contextually and topically redefined patrimonium. The third type would be a rationalized patrimonialism with a pragmatically operationalized patrimonium.

Although Weberian dimension may be occasionally interpreted with a tinge of evolutionary vision such occasions are purely contextual and history in- 


\section{Redescriptions 18/1}

formed. His typology is evidently not an evolutionary one. This fact makes evolutionary dimension particularly promising. It may help to identify institutional impact of modernization upon power concentration in individual cases. Thus, a non-modern authority can be essentially elemental and primordial with negligible or little impact of modernity diffusion identified in terms of open access and accountability. A proto-modern authority could be influenced by contextual exogenous modernization but would retain its reliance upon closed access and transcendental sanction. A modernizing authority would be immersed by both endogenous and exogenous modernization.

Various patrimonial and other political orders may co-exist, overlap and produce empirical entities that cannot be reduced to a single neatly defined 'type'. Neither concepts nor phenomena replace or substitute their 'predecessors'. In Hegelian terms new phenomena aufheben ('take over', 'overrun') previous ones in a sense of retaining them in an immersed way within their new shapes. Thus, an initial form of patrimonial rule is overrun and retained by series of its new re-appearances each adding up something new and adapting older residue shapes. But some exceedingly simple clue (draft, silhouette, contour, trace) is retained virtually unchanged. It is crucial to identify it both in phenomena and concepts because such a clue is in fact a prototype that provides 'blueprints' for both new and retained forms and their combinations.

Combination of 'pure' Weberian and evolutionary schemata produces more coherent or contradictory mixed types. It is probably one of the reasons why the mixed types on down-up and left-right diagonal look 'normal' and other 'deviant' or even 'impossible'. Still one could find instances of applying schema of modernizing traditional monarchies in Jordan or Oman. Similarly schema of rational-legal but non-modern rule may be identified in small island communities of the Pacific like Tonga or Tuvalu.

The sequence of 'normal' or 'natural' schemata runs from traditional nonmodern through charismatic proto-modern to rational-legal modernizing. Those basic schemata may be extended by supplying additional attributes and parameters into individualized ideal types. Traditional non-modern schema could be extended into patrimonial type, charismatic proto-modern schema to neo-patrimonial type and rational-legal modernizing scheme into caesarist plebescitarian type.

Admixture of bureaucracy and modernity to patrimonialism is a central issue of neopatrimonial debate. "This triple knot—patrimonialism, bureaucracy, and modernity—remains a key to our troubled times" (Charrad \& Adams 2011: 9).

This combination may seem odd and demanding. Long-established and novel qualities, formalized and informal practices would hardly go together. But experience proves that in the overwhelming majority of cases a neopatrimonial component makes it relatively easy to manage complexes governance orders both to the rulers and ruled. 
A possible explanation may be a drastic reduction of demands and expectations to both agency and structure of all the components - patrimonial, bureaucratic, and adopted 'modern' orders. As a result the ensuing practices rest on protean authoritative agency and its blurred functions. With all its variability the dominant authority is seen as essentially integral: to have an authority means to be an authority and visa versa. There is no way to tell apart public and private, office and officeholder although the respective regulations, establishments and set ups are definitely in place.

The emerging fuzziness of practices does not prescribe vagueness and ambiguity of scholarly analysis. On the opposite it must be very clear and go beyond superficial appearance of the factual particulars however telling they may seem at the first glance. To better understand the perplexing knot of heterogeneous phenomena one has to resort to highly detached and definite analytical distinctions of each of its components.

Within the context of conceptual stretching patrimonial and patrimonial rule is just a label on a distinct pattern of power relations with very specific properties either within a state or of the entire state (Bach 2013). Those properties may range from rather neutral patronage to nepotism and cronyism and end up with highly charged corruption or even outright predation. Their purpose is to provide a "teleological explanation of the decline of the state" in an individual case or a handful of cases. As a result "cross-cutting grid of analysis [is] still missing" (Bach 2012: 2).

The purpose of this article is elaboration of conceptual tools that could be applied to a broad range of individual cases and serve as a common profile denominator for them. Any event or phenomenon is individual and unique but all can be studied as comparable phenomena in their own right. Thus, within the research addenda of this article it is much more appealing to look not so much for unique embodiment(s) of patrimonialism (as do majority of neopatrimonialism scholars) but for an analytical instrument that may help to identify patrimonial characteristics in a variety of cases.

\section{Functions and dysfunctions of patrimonialism}

Many researchers of patrimonalism and related phenomena typically focus their interests on ensuing evils and harms of specific problematic cases. This contextual and subjective predisposition instinctively moves them to defining respective phenomena by their negative manifestations or dysfunctions, e.g. personal favors, nepotism, cronyism, corruption, predation, factionalism, bribery, extortion, graft, fraud, racket, repression, godfatherism, warlordism etc. Thus, they are treated as essentially dysfunctional. 


\section{Redescriptions 18/1}

How is it reflected in their mental instruments? It depends what kind of intellectual device is actually used. The buzzword would simply emotionally reinforce predispositions on patrimonialism. A homogeneous concept would consistently sieve and highlight dysfunctional properties of patrimonial phenomena leaving all the other 'invisible' and thus non-comprehendible. acknowledged recognized

The nuclei of heterogenous or stratified concepts would focus on dysfunctional aspects. They would be exaggerated and the functional ones played down. This approach could be called dysfunctional definition fallacy. It is hard to believe but in social sciences claiming to be value-free (wertfrei) this fallacy is very common. Both neopatrimonialism and autocracy are predominantly comprehended in this negative-dysfunctional mode.

Imagine we apply such a fallacy to democracy. Let corruption, fraud and electoral misuse be used as criteria, then standard cases would be crippled democracies while well-established democracies would turn out nothing but queer deviations. No doubt dysfunctional definition fallacy would relate patrimonialism to kleptocracy, predatory state, dictatorship, godfatherism, warlordism, capture, etc. The question is what could be the result of functional definition of patrimonialism. Unfortunately this type of definition is not widespread in neopatrimonialism literature.

As noted by Daniel Bach, the concept has become a "teleological explanation of the decline of the state" quite comparable to the notion of the "anti-development state". And normative 'decline of the state' is interpreted as equally normative demodernization. Still a closer analysis shows many more complex examples of empirical states that are simultaneously patrimonial and developing. One must therefore separate neopatrimonialism within the state from patterns of neopatrimonialism that permeate the entire state (Bach 2013).

It would be auspicious to go further and to distinguish the framework order of a state and autonomous orders within a state. Moreover, it may be often necessary to identify complex nature of the framework order of a state and acknowledge combination of its component framework patterns of various kinds (patrimonial, authoritarian, democratic etc.).

Functional aspects of neopatrimonialism have been discussed in anthropological studies. But even there they are not numerous. If we leave out studies in historical anthropology like highly informed and deep analysis of Botswana (Tswana) kingdoms or rather complex chiefdoms by Ørnulf Gulbrandsen (Gulbrandsen 1995) only very few would remain. They include Hans Bakker's analyses of Indonesian patrimonial prebendarism (Bakker 1987; Bakker 1997) and Douglas Webber's work on consolidated patrimonial democracy also in Indonesia (Webber 2006).

Another example of functional interpretation of patrimonialism could be found in Russian and Post-Soviet studies. A range of publications and doctoral 
habilitation dissertation of Alexander Fisun are particularly impressive. Henry Hale discusses patrimonial democracy in Post-Soviet Eurasia (Hale 2005). A more recent article by Steve Hanson deserves attention (Hansen 2011).

This obvious deficit proves urgent need to clarify functional properties of patrimonialism. One can follow Max Weber and concentrate on the ruler(s) and the manner of his (their) control over the populace. There are evident limits to such an approach. First, it is difficult to extend analysis beyond reverence of subjects to authority or their predisposition to legitimize their principals and accept their manner of governing. Second, an unchallenged manner of rule would work anyway with no incentives to improve.

In my view a key mental 'clue' for patrimonialist thinking and behaviour is a common frame of reference. It is their inalienable common good, their 'heritage', 'patrimony' implanted and passed over from generation to generation. They all equally share this patrimony but it has to be cared, maintained and provided by a patriarch - one of them but the best of all since he has better access to a transcendental source of a tradition.

This common good of generations, their revered heritage and patrimony is a morphological 'blueprint' (Patzelt 2007; Patzelt 2012). It is not just a metaphor but a theoretical as well as analytic instrument of evolutionary morphology of politics. Polities that employ such a 'blueprint' could be considered patrimonial insofar as the 'blueprint' is used.

In its historical or rather morphological sense patrimonialism is a manner of rule when the ruler and the ruled depart from the shared perspective of a single authority residing within their common patrimony of successive generations. As a consequence both the ruler and the ruled do not distinguish between personal and public patrimony, patrimony as substance and legal entitlement (those are evolutionary later analytical distinctions). They would not tell apart material and all other resources of a community from the agency and properties the ruler.

Genuine or 'pure' brands of patrimonialism close to the above research prototype are near extinct. Rare examples can be found in distant climes and exotic surroundings where relative isolation helped to preserve primordial ways and habits. In this article a broader morphological understanding of the term is applied. The absence of distinctions and differentiations is treated not as actual one but conditional or rather 'imaginary'. People do understand that common wealth and the right to use it, collated power and entitlement to authority are different things, but in their good faith they still believe it is proper to act as if all power and matters of mutual concern were amalgamated for the sake common good and prosperity.

There are conflicting ideas on the ability of patrimonial orders or rather patrimonial component of complex orders to serve as vehicle of modernization and even democratization. Functionality and particularly dysfunctionality of 46 


\section{Redescriptions 18/1}

patrimonialism turn very problematic in this regard. On the other hand there no structural obstacles to redefine patrimonium democratically. In his article "Can Neopatrimonialism Dissolve into Democracy?" Mamoudou Gazibo fairly convincingly showed that neopatrimonialism could fuse with democracy within hybrid regimes of "new democracies" in the post-Communist space or "third wave democracies" in Latin America (Gazibo 2012). There are regimes that are more accountable to public opinion and even be strengthened by efficiency reforms, as shown in the case of Zambia (Soest 2007).

What about prospect of democratizing patrimonial political orders in the ongoing passion for democracy in Middle East and other parts of the world? Resorts to patrimonialism, neo-patrimonialism and caesarism are imminent. They are too firmly entrenched in the tradition. But it is also clear that their use would never be as strong and persistent as it was and has been recently. Their exercise would be ever more diversified and more pointedly related to varying contexts. And what is equally important personal rule and uncontested domination in politics have slimmer chances in the decades to come. The change would not be easy and momentary. It is quite probable that transition countries would live through a series of entries and reentries of strongmen as its heads of state. But is equally probable - they would share more power, they would delegate more authority and they would become more accountable.

\section{Tentative conclusions}

An answer to the question posed in the title of the article can be quite simple. Yes, the terms patrimonialism and neopatrimonialism can be attached to any kind of conceptual device from a normative concept to an ordinary language word and even catastrophically end up in a buzzword. Yes, it can refer to abstract ideas, instrumental concepts, exemplar notions or types or empirical objects extracted from phenomenal world by way of conceptualization. But those short answers can hardly be satisfactory. They were implied already in the introduction. Has the article produced any added value? It has.

The first and the most important finding is that in fact there is not a single term patrimonialism with its derivative neopatrimonialism but a range of homonymous and crucially different terms. Inability to recognize it leads to selfdeception and conceptual blurring. Moving up and down the Sartorian ladder of abstraction (Sartori 1970) we do not remain equipped with one and the same conceptual instrument as Giovanni Sartori implied in his seminal article. On each step we have to make a decision - either to replace a conceptual instrument we used previously by a new one, or to redeploy and readjust both capacities and reference of respective analytical tool. Since the movement back and forth along the ladder of abstraction is tightly intertwined with the very 
pathway of reasoning an investigator has to be on alert and carefully sort out available conceptual tools selecting the appropriate ones.

Another finding has to do with the reference of the terms. It is never the the real thing' or 'entire phenomenon'. What we call patrimonialism, consumerism, capitalism, democracy or globalization do not cover and exhaust entire life episode we study but are rather our own conceptual extractions of its aspects. A singular occurrence of life, say all we confront stepping out our university building and going out to the streets of our home town, meeting people, making deals etc. may well can be a combination of patrimonialism, consumerism, capitalism, democracy or globalization and dozens of other things conceptually extracted by our minds.

In turn this allows our minds not to hide behind a screen of shallow claims that the world out there is only patrimonial or only corporate but undertake a daring study of an intricate arrangement of projections we managed to conceptually extract. That makes the whole project of studying patrimonialism far more meaningful and promising then it is now.

\section{References}

ANDRESKI, Stanislav, 1984. Max Weber's Insights and Errors, London, Routledge and Kegan Paul.

ANDRESKI, Stanislav, 2013. ed. Max Weber on capitalism, bureaucracy and religion. Vol. 4. Routledge.

ARONOVITCH, Hilliard, 2012. "Interpreting Weber's Ideal-Types" Philosophy of the Social Sciences 42.3, 356-369.

BACH, Daniel, 2013.'Patrimonialism and neopatrimonialism. Comparative Receptions and Transcriptions'. In Bach D.C. \& Gazibo M. (eds.) Neopatrimonialism in Africa and Beyond. L. and N.Y.: Routledge.

BACH, Daniel \& Mamoudou Gazibo (eds.) 2013. Neopatrimonialism in Africa and beyond. Routledge.

BAEHR, Peter, 2004. 'Max Weber and the Avatars of Caesarism'. In Baehr P. \& Richter M. (eds.) Dictatorship in history and theory. Bonapartism, Caesarism, and Totalitarianism. Cambridge: Cambridge University Press, 155-174.

BAKKER, J.I. (Hans) 1987. Class Relations in Java in Nineteenth Century: A Weberian Perspective. - Canadian Journal of Development Studies, 137-156.

BAKKER, J.I. (Hans) 1997. Weber's Pure Ideal Type Model of Patrimonial Prebendarism: Testing the Applicability of the Model in Indonesia. - Paper for the $92^{\text {nd }}$ Annual Meeting of ASA, August 9 - 13 .

BELOW, Georg von, 1914. Der deutsche Staat des Mittelalters, ein Grundriss der Deutschen Verfassungsgeschichte. Leipzig: Quelle \& Meyer.

BRATTON, M. \& van de Walle, N. 1994. "Neopatrimonial Regimes and Political Transitions in Africa". World Politics, 46: 4, 453-489.

BRUGMAN, C. \& Lakoff, G. 1988. 'Cognitive topology and lexical networks'. In 


\section{Redescriptions $\quad 18 / 1$}

Small, S. et al. (eds.), Lexical Ambiguity Resolution: Perspectives from Psycholinguistics, Neuropsychology, and Artificial Intelligence, San Mateo, CA: Morgan Kaufmann, 477-508.

BRUGMAN, C. \& Lakoff, G. 2006. 'Chapter 3. Radial network. Cognitive topology and lexical networks'. In Geeraerts, Dirk (ed.) Cognitive Linguistics: Basic Readings. B.: Mouton de Gruyter,109-139.

BRUHNS, Hinnerk, 2006. 'Max Webers 'Grundbegriffe' im Kontext seiner wirtschaftsgeschichtlichen Forschungen.' In Lichtblau, Klaus (hsgb.). Max Webers' Grundbegriffé: Kategorien der kultur- und sozialwissenschaftlichen Forschung. WiesBaden: Verlag für Sozialwissenschaften, 151-183.

BRUUN, Hans Henrik, 2012. Science, Values and Politics in Max Weber's Methodology: New Expanded Edition. Ashgate Publishing, Ltd..

CHARRAD, M.M. \& Adams, J. 2011. "Introduction: Patrimonialism, Past and Present". In The ANNALS of the American Academy of Political and Social Science, vol. 636, 6-15.

EISENSTADT, Smuel, 1973. Traditional Patrimonialism and Modern Neopatrimonialism. London: Sage Publications.

ERDMANN G. \& Engel U. 2007. "Neopatrimonialism Reconsidered: Critical Review and Elaboration of an Elusive Concept". Commonwealth \& Comparative Politics. n 1, 95-119.

EVANS, Peter, 1992. "The State as Problem and Solution: Predation, Embedded Autonomy and Structural Change." In Stephan Haggard, Robert. R. Kaufman, eds., The Politics of Economic Adjustment: International Constraints, Distributive Conflicts, and the State. Princeton: Princeton University Press, 139-181.

GAZIBO, Mamoudou, 2012. "Can neopatrimonialism dissolve into democracy?" Daniel Bach and Mamoudou Gazibo (eds.), Neopatrimonialism in Africa and Beyond. London and New York: Routledge, 79-89.

GERRING, John. 1999. 'What makes a concept good? A criterial framework for understanding concept formation in the social sciences'. Polity, 357-393.

GULBRANDSEN, Ø. 1995. The King Is King by the Grace of the People: The Exercise and Control of Power in Subject-Ruler Relations. - Comparative Study of Society and History, vol. 1995.

HALE, Henry, 2005. "Regime Cycles: Democracy, Autocracy, and Revolution in PostSoviet Eurasia”. World Politics, vol. 58, \#1, pp.133-156.

HALLER, Karl Ludwig von. 1816-1834. Restauration der Staats-Wissenschaft oder Theorie des natürlich-geselligen Zustands der Chimäre des künstlich-bürgerlichen entgegengesezt: Darstellung, Geschichte und Critik der bisherigen falschen Systeme: allgemeine Grundsäze der entgegengesezten Ordnung Gottes und der Natur. 6 Bde. Winterthur: Steiner.

HANSEN, Stephen, 2011. Plebiscitarian Patrimonialism in Putin's Russia: Legitimating Authoritarianism in a Postideological Era. In The ANNALS of the American Academy of Political and Social Science, vol. 636, 32-49.

HERMES, Siegfried, 2003. Soziales Handeln und Struktur der Herrschaft. Max Webers verstehende Soziologie am Beispiel des Patrimonialismus. Berlin: Duncker \& Humblot.

HERMES, Siegfried, 2006. "Der Staat als 'Anstalt': Max Webers soziologische Be- 
griffsbildung im Kontext der Rechts- und Staatswissenschaften“. In Lichtblau, Klaus (hsgb.). Max Webers' Grundbegriffe': Kategorien der kultur- und sozialwissenschaftlichen Forschung. Wiesbaden: Verlag für Sozialwissenschaften, 184-216.

IKELS, Charlotte. 2004. Filial piety: Practice and discourse in contemporary East Asia. Stanford: Stanford University Press.

KALBERG, Stephen, 1994. Max Weber's Comparative-Historical Sociology. Cambridge, Polity Press, 96-97.

KALBERG, Stephen 2013. Max Weber's comparative-historical sociology today: major themes, mode of causal analysis, and applications. Farnheim: Ashgate.

MASLOVSKI, Mikhail, 1996. "Max Weber's concept of patrimonialism and the Soviet system”. Sociological Review. 1996: 2, 294-308.

МАСЛОВСКИЙ, М. В. 1997. Теория бюрократии Макса Вебера и современная политическая социология. Н. Новгород: Изд-во ННГУ.

MEDARD, J.-F. "L'État néo-patrimonial en Afrique noire", in Médard Jean-François (ed.), Etats d'Afrique noire : formation, mécanismes et crises, Paris: ed. Karthala, coll. "Hommes et sociétés", 356-365.

MOHL, Robert von, 1844. Die Polizei-Wissenschaft nach den Grundsätzen des Rechtsstaates. Bd. 1, 2. Aufl., Tübingen: Mohr.

MOHL, Robert von, 1856. Die Geschichte und Literatur der Staatswissenschaften: In Monographieen dargestellt. Bd. 2. Erlangen: Enke.

NORVIG, P \& Lakoff, G. 1987. 'A Study in Lexical Network Theory'. Proceedings of the Thirteenth Annual Meeting of the Berkeley Linguistics Society, 195-206

PATZELT, Werner, (Hg.) 2007. Evolutorischer Institutionalismus. Würzburg: Ergon Verlag.

PATZELT, Werner, (Hg.) 2012. Parlamente und ihre Evolution. Baden-Baden: Nomos.

PIPES, Richard, 1995. Russia under the old regime. With new forward to the second edition by the author. Harmondsworth: Penguin Books (first published in 1974).

PITCHER, A., Moran M. H., Johnston M. 2009. Rethinking Patrimonialism and Neopatrimonialism in Africa. African Studies Review, 52: 01, 125-156.

ROSCH, Eleanor Heider. 1973. 'Natural categories'. Cognitive Psychology. 4: 3, 328-350.

ROSCH, Eleanor. 1978. 'Principles of categorization'. In E. Rosch \& B. B. Lloyd (Eds.), Cognition and categorization. Hillsdale, NJ: Lawrence Erlbaum Associates, 27-48.

ROSCH, Eleanor Heider \& C.B. Mervis. 1975. 'Family resemblances: Studies in the internal structure of categories'. Cognitive Psychology, 7, 573-605.

ROTH, G. 1968. 'Personal Rulership, Patrimonialism, and Empire-Building in the New States'. World Politics, Vol. 20:2, 194-206.

SARTORI, Giovanni 1970. 'Concept misformation in comparative politics'. The American Political Science Review, 94, 1033-1053.

SCHÜRMAYER, Ignaz Heinrich (1856) Handbuch der medicinischen Policei: Nach den Grundsätzen des Rechtsstaates, zu academischen Vorlesungen und zum Selbstunterrichte für Ärzte und Juristen. Erlangen: Enke.

SOEST von, Ch. 2007. "How Does Neopatrimonialism Affect the African State? The Case of Tax Collection in Zambia." Journal of Modern African Studies 45: 4: 621645. 


\section{Redescriptions $\quad 18 / 1$}

SOEST von, Ch. 2010. What Neopatrimonialism Is - Six Questions to the Concept. Background paper for GIGA-Workshop "Neopatrimonialism in Various World Regions". Hamburg: GIGA, 2010.

TOLMAN, Edward Chace, 1948. 'Cognitive maps in rats and men'. Psychological Review, 55, 189-208.

TRAYLOR K. L. 1988. Chinese filial piety. - Bloomington : Eastern Press.

WEBBER D. 2006. "A Consolidated Patrimonial Democracy? Democratization in Post-Suharto Indonesia”. Democratization 13:3, 396-420.

WEBER, Max 1904 [1973]. Die "Objektivität" sozialwissenschaftlicher und sozialpolitischer Erkenntnis. In Johannes Winckelmann (Hg.), Gesammelte Aufsäze zur Wissenschaftslehre. Tübingen: Mohr. 146-214.

WEBER, Max. 1994. 'Parliament and Government in Germany under a New Political Order'. In Lassman R. \& and Speiers R. (eds), Weber: Political Writings, Cambridge: Cambridge University Press, 130-271.

WEBER, Max. 1980. Wirtschaft und Gesellschaft. Grundriß der verstehenden Soziologie. 5. revidierte Auflage besorgt von Johannes Winckelmann. Studienausgabe, Tübingen: Mohr (first published by in 1922).

WOODS, D. 2012. Patrimonialism (neo) and the Kingdom of Swaziland: employing a case study to rescale a concept. Commonwealth \& Comparative Politics, vol. 50: 3, 344-366. 